\title{
A maszkulin és heteroszexuális köztér termelése Elméleti háttér a társadalmi tértermelésnek a búncselekményektől való félelem kontextusában történő kutatásához
}

\author{
The production of masculine and heterosexual \\ public spaces \\ Theoretical background for the study of the \\ social construction of space in the context \\ of fear of crime
}

\author{
MOLNÁR ANDRÁS
}

KULCSSZAVAK: köztér, társadalmi tértermelés, büncselekményektől való félelem, társadalmi nem, szexualitás

ABSZTRAKT: A nyugati országokban feminista földrajzi kutatások keretén belül már az 1980-as években elkezdtek foglalkozni a közterekhez kötődő félelem földrajzával, Magyarországon viszont a tér, a társadalmi nem és a félelem összefüggéseinek földrajzi vizsgálata még újdonságnak számít. Pain (2000) szerint azért fontosak az ilyen irányú vizsgálatok, mert a társadalmi hatalmi egyenlőtlenségek feltérképezését szolgálják, továbbá a félelem a térhasználó emberek életminőségének alakításában is fontos szerepet játszik. Mivel a téma kutatása még nem kezdődött el Magyarországon, ezért e tanulmány célja bepillantást nyújtani a vonatkozó külföldi irodalomba, illetve annak bemutatása, hogy az ilyen jellegű kutatások miképpen járulhatnak hozzá a földrajzi tudás szélesítéséhez. A köztér fogalmának és jelentőségének tárgyalása (Staeheli, Mitchell 2007) után a maszkulin és heteroszexuális közterek termelését Valentine (1996) elméletének bemutatása segít megérteni, amelynek alapját a társadalmi nem performativitásáról alkotott butleri felfogás szolgáltatja. A búncselekményektől való félelemhez kapcsolódó tértermelés értelmezésére pedig főként Valentine (1992), Koskela (1997, 2000) és Brownlow (2005) írásaira alapozva kerül sor. A tanulmány amellett érvel, hogy az ilyen irányú feminista földrajzos vizsgálódások színesititk a térről és a térhasználó emberekről alkotott felfogásunkat, és emellett közelebb visznek a társadalmi egyenlőtlenségek okainak megértéséhez. 
KEYWORDS: public space, social production of space, fear of crime, gender, sexuality

ABSTRACT: While the research into public space and fear of crime became a popular topic with some Western European feminist geographers in the 1980s, in Hungary a geographical investigation into the interaction of space, gender and fear of crime has never been carried out. According to Pain (2000), the study of fear of crime is important because it provides an understanding of social power relations and the related inequalities, and it is also crucial because fear strongly affects people's quality of life. Since it is a non-existing topic in the history of Hungarian geographical research, this paper aims to summarise the findings of the relevant foreign literature to suggest how an enquiry like this can contribute to the further advancement of geographical knowledge production. After the discussion of the definition and significance of public space (Staeheli and Mitchell 2007), the reader is presented with an understanding of space which is socially produced and comes about as a result of the interaction of gender, sexuality and fear of crime. It is Valentine's (1996) spatial theory, which is based on the theory of gender performativity originally developed by Butler, that helps explain the social production of masculine and heterosexual spaces. The description of the process of the fear of crime-related production of space is then based on the works of, mainly, Valentine (1992), Koskela (1997, 2000) and Brownlow (2005). This paper suggests that feminist geographical research projects could extend our understanding of space, i.e. contribute to the development of spatial theory, and also help us gain insight into the ways people relate to space. Furthermore, they help us understand the reasons behind social inequalities.

\section{Bevezetés}

A nyugati országokban feminista földrajzi kutatások keretén belül már az 1980-as években elkezdtek foglalkozni a közterekhez kötődő félelem földrajzával (Valentine 1989). Ezek a vizsgálatok a térkutatás olyan megközelítését jelentették, amely érdeklődésének középpontjában a tér megélése és az ezt befolyásoló tényezők álltak. A magyar geográfia e téma részletes kutatásával azonban még nem foglalkozott. A félelem földrajzát mint új geográfiai témát Timár (2002) említi a feminista földrajzról írt ismertetőjében. Mivel a félelemföldrajzi kutatások a feminista földrajzban gyökereznek, nem meglepő, hogy Magyarországon nem találkozunk velük, hiszen hazánkban a feminizmus még napjainkban is valamiféle szitokszónak számít, illetve az eltérő társadalmi-gazdasági kontextus következtében egyes nyugati feminista elméletek csak nehézkesen alkalmazhatók magyar viszonylatban (Timár 1993). Pedig a feminista földrajz megközelítésmódjával, újszerű problémafelvetéseivel új lehetőségeket nyit meg a földrajzi kutatások központi kategóriáinak, a térnek, illetve az azt használó embereknek a vizsgálatában.

E tanulmány - a fóként angol-amerikai tapasztalatból táplálkozó szakirodalom áttekintésén keresztül - olyan feminista földrajzi elméleti keretet vázol fel, amely alkalmas lehet a társadalmilag termelt tér, a társadalmi nem és szexualitás, illetve a bűncselekményektől való félelem 
összefüggéseinek vizsgálatára, és további (akár empirikus) kutatásra sarkallhatja az érdeklődőket.

Mivel Magyarországon a közterek földrajzi kutatása maga sem széles körben elterjedt, ezért az elméleti áttekintést Staeheli és Mitchell (2007) tanulmányának ismertetése indítja. Eredményeik azt támasztják alá, hogy a közterek kutatását a nyugati geográfiában aktív érdeklődés övezi. Ezután a köztér demokratikus térként való értelmezésére kerül sor (Staeheli, Mitchell 2009, Young [in Paddison, Sharp 2007], Valentine 1996), illetve szó esik azokról a problematikus pontokról, amelyekre a közterek kutatása során figyelmet kell fordítani. Ezt követően Valentine (1996), Nameste (1996), valamint Duncan (1996) elméletein keresztül bemutatásra kerül, hogy egyes feminista geográfusok miként értelmezik a maszkulin és heteroszexuális köztér termelését. Valentine (1996) a társadalmi nem performativitásáról alkotott butleri elméletre alapozva magyarázza a közterek heteroszexuális térként való termelődését, illetve rámutat a szexualitás és társadalmi nem közti összefüggések fontosságára. Duncan pedig a társadalmi nem és a szexualitás tárgyalásában kiemelt fontosságúnak tartja a társadalmi nemi viszonyok által áthatott nyilvános/magán distinkció vizsgálatát, ugyanis azon a véleményen van, hogy a nyilvános/magán szétválasztását célzó „ideologikus forgatókönyv” előírásaival összhangban termelődnek a maszkulin, illetve feminin terek.

A tanulmány második fele egy olyan feminista földrajzi elméleti keretet vázol fel, mely a társadalmi tértermelés elméletének a bűncselekményektől való félelem kontextusába történő helyezését segíti. A témával való foglalkozás jelentőségét Pain (2001) igazolja. Véleménye szerint azért fontosak az ilyen irányú kutatások, mert a félelem egyértelműen befolyásolja az egyének életminőségét, illetve vizsgálata a társadalmi hatalmi egyenlőtlenségek feltérképezését is szolgálja. Koskela (2009) rámutat, hogy a tértermelési nézőpont megértését segíti a félelem társadalmi konstrukcióként való tárgyalása. Ennek magyarázatára olyan elméletek áttekintésére kerül sor, amelyek a családnak és szocializációnak (Valentine 1992, Yeoh, Yeow 1997), a „köztereken félős nő” mítoszának (Day 2001), valamint a médiának és az informális kommunikációnak (Valentine 1992, Yeoh, Yeow 1997) a maszkulin tér kialakításában betöltött szerepét tárgyalják. Ezután a bűncselekményektől való félelem térbeli következményeinek összegzése következik. Szó esik arról, hogy a biztonságérzet növelésére alkalmazott megbirkózási stratégiák miképp értelmezhetők a társadalmi kirekesztés, illetve a maszkulin és heteroszexuális köztér termeléséről felvázolt elméletek kontextusában (Valentine 1992, Koskela 2000, Brownlow 2005, Starkweather 2007). 


\section{Elméletek a köztérről és a társadalmi tér termelésérôl a társadalmi nem és a szexualitás kontextusában}

\section{A köztér fogalma és jelentósége körüli bizonytalanságok földrajzos szakcikkek és köztérkutató geográfusokkal készített interjúk alapján}

Staeheli és Mitchell (2007) szisztematikus elemezésnek vetette alá az 1945 és 1998 között megjelent angol nyelvü geográfiai szakirodalmat annak felderítésére, hogy a földrajztudomány hogyan definiálja a köztér fogalmát, illetve mi adja e terek jelentőségét. Eredményeik igazolják, hogy a köztérkutatás a kortárs geográfia releváns kutatási témája. A szerzők 218 olyan tudományos cikket, könyvfejezetet, könyvet találtak, amelyek fókuszában a közterek vizsgálata állt, szerzőjük geográfus, illetve adott müvek földrajzos folyóiratban vagy könyvekben jelentek meg. A müveket - többek között - a bennük talált köztér-definíciók, elméleti irányultságuk, empirikus érdeklődésük és alkalmazott kutatási módszereik alapján osztályozták. A szakirodalom áttekintése során olyan kulcsszavakat és kifejezéseket vizsgáltak, amelyeket az adott kutatók a köztérrel azonosítottak. Tehát olyan kategóriákkal dolgoztak, amelyek az irodalomban már léteztek. Így lehetőségük nyílt arra, hogy a definíciókat az előfordulásuk gyakorisága szerint rangsorolják. Második lépésben interjúkészítési szándékkal megkeresték azon cikkek szerzőit, akik rendelkeztek PhD-fokozattal. Összesen 25 ilyen interjút készítettek.

Staeheli és Mitchell (2007) megállapítják, hogy a szakcikkekben, könyvfejezetekben a leggyakoribb definíciók a közterek fizikai valóságával kapcsolatosak $\left(37 \%^{1}\right)$, ezt követik a köztereket találkozási helyként (27\%), majd harmadik helyen az alkudozás/vita/tiltakozás helyszíneiként (23\%) értelmező definíciók. Utóbbi kettő a közterek szociális, illetve demokráciában betöltött fontos szerepére hívja fel a figyelmet. Érdekes módon a tudósokkal készült interjúkban az első helyen a közterek mint a találkozás helyei (44\%) állnak, míg az előző rangsortól eltérően kiugróan magas a közteret az egyén kontrollja alól kieső térként definiálók aránya (44\%). A tudósok által adott definíciók 20-20\%-a alapján a közterek a nyilvános szférát (fizikai megjelenés nélkül), illetve a privát tér ellentétét jelentik. A szerzők szerint ezek az eredmények azt támasztják alá, hogy a geográfusok nyitottak a közterekről való absztraktabb gondolkodásra. Ugyanakkor az irodalmi áttekintés és az interjúk eredményei között megfigyelhető ellentmondás árulkodó arra nézve, hogy milyen nehéz megfogalmazni, mi is a köztér valójában.

A közterek jelentőségét rangsoroló két adatsor (irodalom és interjúk) összevetésekor is ellentmondás érzékelhető. A cikkek alapján a közterekhez kötődő funkciók (pl. sétálás, gyülekezés) adják e terek legfőbb jelentőségét (33\%), de fontosak úgy is mint a szocializáció (30\%) és a demokrácia (30\%) terei. A definíciók áttekintéséhez hasonlóan itt is az tapasztalható, hogy a szakirodalomban kiemelkedő szerepet tulajdonítanak a köztereknek a szociális/közösségi, illetve 
demokratikus folyamatokban. Az interjúkban a tudósok legnagyobb arányban a közterek demokráciában, politikában és társadalmi mozgalmakban betöltött szerepét (32\%) emelték ki. Szintén 32\%-uk tartotta fontosnak közösségépítésben és társadalmi összetartásban való jelentőségüket. A tudósok 24-24\%-a gondolta úgy, hogy a köztereknek fontos szerepe van az identitás kialakulásában és megszilárdításában (Staeheli, Mitchell 2007). Ezek a kategóriák (a demokráciában, a közösségépítésben és az identitás formálásában betöltött szerep) átfedésben vannak vagy lehetnek egymással. Példaként szolgálhatnak olyan politikai éllel is rendelkező mozgalmak, amelyek az identitást állították érvelésük középpontjába (pl. Meleg Felszabadítás [Gay Liberation Movement]) (Jagose 2003). Továbbá az identitás formálásához köthetők azon felfogások is, amelyek a köztereket a városi élet/szórakozás tereiként értelmezik (12\%).

\section{A köztér mint demokratikus tér}

Staeheli és Mitchell $(2009,511$.) természetesen szintén definiálja a közteret, éspedig olyan térként, ,ahol a nyilvánosság formálódik (illetve maga a köztér a nyilvános szféra körül kialakult diskurzuson keresztül konstruálódik), és ahol ennek következtében társadalmi és kulturális szabályszerűségek érvényesülnek". Ha elfogadjuk, hogy a köztér a nyilvános szféra körül kialakult diskurzuson keresztül konstruálódik, továbbá figyelembe vesszük Pratt (2000) megállapítását, miszerint a nyilvános szféra fogalma központi szerepet játszik a demokrácia elméletében és gyakorlatában, akkor egyértelműnek látszik, hogy a köztereknek is szerepük van a demokrácia elméletében és gyakorlatában.

Young (in Paddison, Sharp 2007), illetve Staeheli és Mitchell (2009) munkájában is megjelenik a köztér mint politikai és demokratikus tér problematikája. Véleményük szerint a közterek vizsgálhatók a kirekesztés és befogadás kategóriáin keresztül. Staeheli és Mitchell (2009) arra is rámutat, hogy a köztereken a kirekesztés és erőszak (többek között) a társadalmi nemi viszonyok mentén szerveződik. Ezt támasztja alá Koskela $(2000,111$.), aki szerint „a köztér olyan terület, tér, melyhez a férfiaknak több joguk van, és melyről a nők gyakran kirekesztést szenvednek a zaklatások különböző formái és a férfierőszaktól való félelem által".

Hasonló aggályokat fogalmaz meg Valentine (1996) is, amikor egyik írásában három okkal magyarázza, hogy a köztér („,public space”) helyett miért használja inkább az utca (,street”) elnevezést. Az első ok az, hogy számos úgynevezett köztér (szórakozóhely, bevásárlóközpont, városi park) félig-meddig privatizált, vagyis használatának szabályait meg lehet szabni. Másodikként azt a tényt említi, hogy ezek a terek gyakran nem is tekinthetők köztérnek a „mindennapi nyilvánosan hozzáférhető helyek" értelemben, hiszen ezekről sok ember életkora, faji hovatartozása vagy szexuális orientációja miatt kirekesztődik. Végül felhívja a figyelmet arra, hogy a köz-/nyilvános tér fogalma elhomályosít- 
ja azt a tényt, hogy számos - általában a magánélet szférájába sorolt - viszony (például a szexualitáshoz kapcsolódók) valójában a közterekhez is tartozik.

A fenti áttekintéséből látható, hogy egyes geográfusok úgy fogják fel a köztereket mint társadalmi folyamatok és szabályszerüségek által termelt és szabályozott társadalmi termékeket. Az elméletalkotók arra is rámutattak, hogy az egyes ember közterekhez való hozzáférése, köztérhasználata, ezzel összefüggésben az, hogyan éli meg az adott teret, attól függ, milyen viszonyban áll a társadalmi hatalommal.

\section{A maszkulin és heteroszexuális köztér termelése}

A társadalmi folyamatok által befolyásolt tértermelés gondolata elsőként Henri Lefebvre marxista filozófus La production de l'espace (The Production of Space) című munkájában jelent meg (Gregory 2000). A Valentine (1996) által Butlertől átvett - és jelen tanulmányban alkalmazott - szemléletmód azonban különbözik ettől. Ahogy Mahtani (2004) rámutat, Butler maga nem beszél konkrétan a térről és helyről, ugyanakkor egyes geográfusok az általa kidolgozott performativitáselmélet alapján magyarázzák a társadalmi tér termelését.

Butler $(2006,16$.$) a társadalmi nem performativitásán azt érti, hogy „amit a$ társadalmi nem belső eszenciájaként fogunk fel, azt folyamatos cselekvések sora állítja elő, amelyek a test társadalmi nemmel bíró stilizációján keresztül rögzülnek”, tehát „amit saját magunk „belső” jellegzetességének tételezünk fel, az olyasmi, amit elvárunk és létrehozunk bizonyos testi cselekvések során".

Valentine (1996) ezt a gondolatot használja fel, amikor azt állítja, hogy a térnek nincs semmiféle eszenciája (belső lényege), hanem a térhasználókhoz köthető cselekvések és szabályozások által látszik eleve heteroszexuálisnak. Számos példát említ olyan ismétlésekre/testi cselekvésekre, amelyek a teret heteroszexuálissá teszik: az utcán kézen fogva sétáló és csókolózó heteroszexuális párok, a köztereket elborító hirdetési plakátok ábrázolásai, a heteroszexuális tapasztalat aspektusait tárgyaló köztéri beszélgetések, a köztereken hallható romantikus zeneszámok. A szabályozásokon pedig a homoszexuális emberek különböző módon történő megregulázását érti (rosszalló tekintetek, verbális agresszió, testi erőszak). A szabályozások szükségességét azzal magyarázza, hogy a heteroszexuális tér termelődéséhez a társadalmi nem, biológiai nem és heteroszexuális vágy hármas egységére való törekvés is hozzájárul. Ezzel összefüggésben arra a következtetésre jut, hogy a biológiai nem szerint leosztott és egymás ellentéteként megalkotott társadalmi nemi identitáskategóriák (nő = feminin, férfi = maszkulin), amelyeket a homoszexuális emberek gyakran feszegetnek, ismételgetése/eljátszása útmutatóul szolgál arra nézve, hogy mi számít megfelelő viselkedésnek, öltözéknek a köztereken, és egy bizonyos idő után elkerülhetetlenül a heteroszexuális tér látszatát is kelti. Nameste (1996) is azon a véleményen van, hogy a szexuális nonkonformisták elleni erőszak arra vezethető vissza, hogy 
ezek az emberek nem illeszkednek be a társadalmi nem, biológiai nem és heteroszexuális vágy rendszerébe, ezáltal veszélyeztetik azt a látszatot, hogy a tér természetétól fogva maszkulin és heteroszexuális.

A társadalmi nem és a szexualitás társadalmi tértermelésben fellelhető összefüggését jól példázzák a köztéri plakátok nőábrázolásai. Staeheli és Mitchell (2009) szerint a közterek férfias térként való termelődését segíti elő az, hogy kényelmetlenné teszik e helyeket a nők számára. Példaként a köztereken megfigyelhető szexuális/erotikus tartalmú nőábrázolásokat említik. Ezek álltak Rosewarne-nak (2007) az ausztráliai Melbourne-ben végzett, kültéri reklámplakátokra irányuló vizsgálata fókuszában. Rosewarne (2007) azt a következtetést vonja le, hogy a szexista ábrázolásokban bővelkedő plakátok azt a célt szolgálják, hogy fenntartsák és megerősítsék a közterek maszkulin jellegét azáltal, hogy arra emlékeztetik a nőt, hogy ott szexuális tárgyként, a férfi vizuális élményének biztosítékaként funkcionál.

Valentine (1996) szerint a térhasználók cselekedeteit (ezeken keresztül pedig tértermelésüket) aktívan befolyásolják a társadalmi hatalmi viszonyok, amelyek a társadalmi nem és a szexualitás mentén nem egyenlö mértékben oszlanak el a társadalom tagjai között. Connell (1995) - több más kutatóhoz hasonlóan - az ezekkel a jellemzőkkel bíró társadalmakat patriarchális társadalmaknak nevezi. Véleménye szerint a kortárs európai és amerikai társadalmak hatalommegosztásának legfőbb jellemzője a nők alárendelése és a (heteroszexuális) férfiak dominanciája. Ebből pedig - visszacsatolva az előbbi gondolathoz - az következik, hogy a társadalmi hatalomból eltérő mértékben részesedő személyek és csoportok eltérő cselekvéseket hajtanak végre, vagyis az általuk termelt közterek karaktere a társadalmi hatalmi viszonyok leképeződéseként fogható fel.

Staeheli és Mitchell (2009) már korábban ismertetett definíciója szerint a köztér a nyilvános szféra körül kialakult diskurzuson keresztül konstruálódik. Duncan $(1996,128$.) pedig rámutat a nyilvános és magánszférák elkülönítésének erőteljes társadalmi nemi színezetére. Véleménye szerint ez a megosztottság teszi lehetővé, hogy „a társadalmi nem alapján létrejövő elnyomás és függőségi viszony jogalapot nyerjen". Más elméletalkotókhoz hasonlóan úgy véli, hogy a nyilvános szféra mint ideál hagyományosan a testetlen, az absztrakt, a kulturális, a fizetett munka, a termelés, a cselekvés és a hősiesség fogalmai körül szerveződik, és a maszkulin társadalmi nemi kategóriához köthető. Mivel a közterek a nyilvános szféra körül kialakult diskurzusokban a butleri ismételgetéseken/szabályozásokon keresztül termelődő társadalmi produktumok, egyértelmü, hogy maszkulin jelleget öltenek magukra.

Staeheli és Mitchell (2009) is azt állapítja meg, hogy a köztérről gyakran úgy gondolkodnak mint alapvetően férfias térről. Azt mondják, hogy az „ideologikus forgatókönyv" szerint a nyilvános a férfiassal, a magán pedig a nőiesessel azonosítható. Megjegyzik azonban, hogy ez a megállapítás nem egyenlő azzal, hogy a nők nincsenek jelen a köztereken. Példaként említik a nők nyilvános te- 
rekhez kötődő munkavállalását. Duncan (1996) rendszere szerint a fizetett munka világa eleve a nyilvános szféra részét képezi. Staeheli és Mitchell (2009) azt állítja, hogy a nők fizetett munkában való részvétele nem cáfolja meg azt a tényt, hogy a nyilvános/magán kategóriák ideologikus szétválasztása a patriarchális munkaerő-piaci viszonyok fenntartását szolgálja, és ideologikus igazolást ad arra, hogy a fizetett munka világa olyan tér, amely nem a nő (a feminin szubjektum) helye. Ha ennek ellenére mégis erre a maszkulin terepre merészkedik, akkor megint csak ez az ideologikus megosztottság igazolja azt, hogy nincs joga az egyenlő bánásmódhoz vagy fizetéshez, vélekednek a szerzők. ${ }^{2}$

\section{Búncselekményektől való félelem és társadalmi tértermelés}

\section{A tértermelési nézőpont a búncselekményektôl való félelem vizsgálatában}

A Valentine (1996) által említett, a melegek és leszbikusok felé irányuló agresszió kérdésköre jó átvezetésként szolgál a társadalmi nem és a szexualitás mentén történő tértermelésnek a bűncselekményektől való félelem kontextusában történő tárgyalásához. Pain $(2000,367$.) szerint a bűncselekményektől való félelem úgy értelmezhetö, mint „egyének és közösségek által a lehetséges bűncselekményekre és egyéb kisebb horderejü rendbontásra adott széles spektrumon mozgó érzelmi és gyakorlati reakciók összessége". Pain $(2000,2001)$ e kutatásokat azért tartja fontosak, mert a félelem erőteljesen befolyásolja az egyéni életminőséget, emellett vizsgálata a társadalmi egyenlőtlenségek feltárásában is fontos szerepet játszik. A köztereket megélt terekként, illetve a térhasználók cselekedeteinek következményeként létrejövő termékekként kezelő felfogás egyértelműen rávilágít a bűncselekményektől való félelem vizsgálatának jelentőségére.

Az egyes helyek és a hozzájuk kapcsolódó félelem (illetve fordítva) közti komplex kapcsolatra mutat rá Koskela és Pain, amikor amellett érvel, hogy

„[a] büncselekményektól való félelem komplex folyamatok eredményeként keletkezik, e folyamatok elöre meghatározzák bizonyos helyekkel kapcsolatos vélekedéseinket, azáltal, hogy tudatositják bennünk az áldozattá válás kockázatát: a büncselekményektól való félelem meghatározza a hely jelentését, ugyanúgy, ahogy a hely is kihatással van a büncselekményektól való félelemre" (Koskela, Pain 2000, 278.).

A hely és a hozzá kapcsolódó félelem Koskela (2009) szerint vizsgálható a tértermelési nézőpont alkalmazásával. Ez olyan kutatásokra használható, amelyek a félelem térbeliségét nem a lépték viszonylatában vizsgálják, hanem egyértelműen egy sajátságos térfelfogás alapján. Koskela (2009) hangsúlyozza, hogy e 
nézet szerint a tér anyagi/fizikai és társadalmi dimenziói alapvetően összefonódnak. Kiemeli továbbá, hogy az efféle vizsgálatok arra tesznek kísérletet, hogy azonosítsák azokat a (társadalmi hatalmi viszonyok által erőteljesen befolyásolt) mindennapi gyakorlatokat, amelyek a félelem helyhez kötött újratermelését vagy éppen ennek az újratermelésnek az aláásását szolgálják. A szerző szerint ezen azt kell érteni, hogy a térben meglévő szimbolikus jelentés kerül előtérbe, vagyis nem a tér fizikai valósága a rémisztő, hanem az, amit jelképez. Azon a véleményen van, hogy a büncselekményektől való félelmet úgy érthetjük meg, ha az érzelmekhez és társadalmi hatalmi viszonyokhoz kötődő tértermelés tükrében vizsgáljuk.

Koskela (2009) a tértermelési nézőponttal kapcsolatban megállapítja, hogy az úgy tekint a félelemre mint társadalmi konstrukcióra. Ennek a gondolatnak a részletesebb vizsgálata megmutatja, hogy az elméletalkotók szerint a társadalmi hatalmi viszonyok által befolyásolt félelem miként járul hozzá a közterek maszkulin (és heteroszexuális) terekként való kódolásához/termeléséhez.

A család és szocializáció szerepét illetően Valentine (1992) úgy véli, hogy a család intézménye körül keringetett patriarchális ideológiának köszönhetö, hogy a (gyakran bántalmazott) nők továbbra is abban a hitben élnek, hogy a magánszféra biztonságos menedékhely, míg a köztereket a férfierőszakkal azonosítják, ezáltal hozzájárulnak a közterek maszkulin karakterének erősítéséhez. Yeoh és Yeow (1997) kiemeli a családban történő szocializációt mint a félelem társadalmi konstrukciójának fontos elemét. A szerzők szerint az anyák azzal, hogy lányaik védelmét általában a barátjukra bízzák, azt az üzenetet közvetítik, hogy egy nő nem tudja megvédeni magát. Továbbá azáltal, hogy bizonyos helyeket veszélyesként könyvelnek el, illetve korlátozzák lányaik mobilitását, mintegy rájuk örökítik az egyes környékektől való félelmeiket.

A félelem társadalmi konstrukcióként való értelmezését segíti, ha vizsgálat alá kerül a kortárs feminin és maszkulin identitások szervezödése a félelem kontextusában. Day (2001) irwine-i kísérlete során azt vizsgálta, hogy a köztereken sebezhető és védelemre szoruló nőkről keringő mítosz hogyan járul hozzá a kortárs maszkulin társadalmi nemi identitások kialakulásához. Arra az eredményre jutott, hogy a feminin társadalmi nemi identitás alapvető szervezőeleme a köztereken való rettegés/félelem. Day azt mondja, hogy „a férfiak nagy valószínűséggel nem utasítják el a félős nő sztereotípiáját, egészen addig, amíg ezek az előítéletek az általuk vágyott maszkulin identitások (,a védelmezo”) megerősítését szolgálják" (Day 2001, 120.).

A média is fontos szerepet játszik a félelem közterekhez rendelésében. Valentine (1992), továbbá Yeoh és Yeow (1997) kimutatta, hogy a bünügyi hírek fontos térbeli információforrásként értelmezhetők a nők félelemre alapozott mentális térképeinek kialakulásában. A kutatásaikban megszólaló nők emlékezetében élénken éltek a média által bemutatott közterekhez kötődő büncselekmények képei, és ez segítette őket abban, hogy mentális térképet fejlesszenek ki a veszélyes, elkerülendő helyekről (parkok, sötét gyalogösvények). 
Yeoh és Yeow (1997) szerint az informális kommunikáció (pletyka) lehetőséget biztosít olyan hírek terjesztésére, amelyek a média figyelmét elkerülik, emellett teret enged az egyéni értelmezéseknek például a felelősség kérdésében, továbbá fontos szerephez juthat a megoldatlan rendőrségi ügyek esetén is. Következtetésük az, hogy az informális hírcsatornák a feszültség fokozását is szolgálják, továbbá hatással vannak a közösségbe tartozó nők (és férfiak) félelemhez kötődő mentális térképeinek alakulására és a térhasználóknak az adott környék elkerülését eredményező döntéseire.

\section{A bứncselekményektöl való félelem térbeli következményei}

Az előző alfejezetben arról volt szó, hogyan zajlik a közterek veszélyes térként kódolása, illetve arról, hogy ezt a folyamatot miként hatják át a társadalmi nemi, társadalmi hatalmi viszonyok. A továbbiakban a büncselekményektől való félelemnek, illetve a csökkentésére alkalmazott megbirkózási stratégiáknak a kirekesztő közterek termelésében és a társadalmi hatalmi erőviszonyok konzerválásában betöltött szerepéről esik szó a szakirodalom áttekintésén keresztül.

Koskela (2000) szerint egy geográfus szempontjából a nők életét befolyásoló események és történések akkor kezdenek el különösen érdekesek lenni, amikor a nők társadalmi tapasztalatai térbeli következményekkel járnak. Azon a véleményen van, hogy a félelem miatt a nők közterekhez való hozzáférése, illetve a közterekhez kapcsolódó cselekedeteik is korlátozódnak.

Ezt a megállapítást támasztja alá Day (2001), azt állítva, hogy a közterekhez és használatukhoz kötődő félelem az USA-ban élő nők jelentős részét aggasztó jelenség. Egy 1996-ban készült központi statisztikára hivatkozik, amely szerint a nők 55\%-a nyilatkozott úgy, hogy fél, ha sötétedés után a lakóhelye környékén egyedül kell sétálnia. Day úgy gondolja, hogy a büncselekményektől és az áldozattá válástól való félelem erőteljesen korlátozza a nőket abban, hogy a köztereken szabadon, saját kedvükre tevékenykedhessenek.

Valentine $(1989,1992$.$) szerint az, hogy bizonyos környékeket férfierőszakkal$ azonosítanak, komoly hatással van a nők mindennapi térhasználatára. Útvonalaik kiválasztását erőteljesen befolyásolják a félelemérzet csökkentésére alkalmazott megbirkózási stratégiák. Valentine úgy gondolja, hogy ezáltal a nők köztérhasználata korlátozódik. Koskela (2000) szerint, ha vizsgálat alá vesszük a megbirkózási stratégiákat, akkor feltárható, hogy a társadalmi nemi erőviszonyok következtében létrejövő egyenlőtlenségek hogyan kapcsolódnak össze azokkal a térbeli korlátokkal, amelyeket számos nő megtapasztal mindennapi köztérhasználata során.

A megbirkózási stratégiák két nagy csoportjával foglalkozik a földrajzos szakirodalom. Brownlow egyetért Miehtevel (in Brownlow 2005, 583.) abban, hogy a védekező (elővigyázatosságból alkalmazott) stratégiák „olyan magatartásformák vagy tevékenységek, amelyek a bűncselekményeknek való ellenállást célozzák, vagy annak az esélyét igyekeznek csökkenteni, hogy a bántalmazás be- 
következzék." Példaként bizonyos fegyverként használható tárgyak magunkkal hordozását, támadás esetére elméleti tervek kidolgozását és a környék körültekintő vizsgálatát említi.

A védekezőstratégiák fó célja az, hogy az őket alkalmazó személy ne veszítse el a kontrollt a környezete felett (Brownlow 2005, Starkweather 2007). Brownlow kiemeli azt, hogy míg a férfiak esetében a kontroll azt jelenti, mennyire tudják kezelni az adott helyzetet és befolyásolni az erőszak bekövetkezését például intelligencia, erő, agresszió segítségével, addig a nők esetén nagyobb arányban fordulnak elő az úgynevezett eszes/érzékeny kontrolltechnikák, mint például a konzervatív öltözködés vagy a magukat bolondnak tettetés.

Az elkerülés mint stratégia ezzel szemben úgy értelmezhető, mint egyes veszélyesnek vagy kockázatosnak tartott emberektől, helyektől, helyzetektől bizonyos időben való szándékos távolmaradás. E stratégia alkalmazása esetén az ember elfogadja, hogy térhasználata időbeli és/vagy térbeli korlátok közé szorul (Brownlow 2005, Starkweather 2007).

Brownlow (2005) véleménye szerint az elkerülés a nők és férfiak között is a leggyakoribb stratégia, Stankora hivatkozva mégis azt állítja, hogy a nők jóval gyakrabban alkalmazzák ezeket, mint a férfiak. A Starkweather (2007) ohiói diákokat vizsgáló kutatásában megkérdezett azon 67 diák közül, akik beismerték, hogy alkalmaznak elkerülőstratégiát, csak három volt férfi. A nemek közti eltérések magyarázataként Brownlow rámutat arra, hogy mivel az elkerülőstratégiák a félelemmel és gyengeséggel azonosítódnak, a domináns férfiasság diskurzusán belül nem sok tolerancia mutatkozik ezek irányába, és azokat a férfiakat/fiúkat, akik ezeket alkalmazzák, gyakran leköcsögözik, lekislányozzák. A stratégiákat alkalmazó férfiakkal szemben tanúsított ilyesfajta bánásmód visszavezet Valentine-nak (1996) a maszkulin és heteroszexuális köztér termeléséről felvázolt elméletéhez.

Brownlow (2005) szerint a fent említett stratégiák visszatükrözik és újratermelik a társadalmi nem körül felépített diskurzusokat, ezáltal a társadalmi hatalmi viszonyok fenntartását segítik elő. Ezt támasztja alá Koskela $(1997,2000)$ megállapítása is, miszerint a nők köztérhasználathoz kötődő magabiztossága (vagy ennek hiánya) a társadalmi nemi erőviszonyok indikátora lehet. Véleménye szerint az erőszaktól való félelem által befolyásolt cselekvések következtében a városi utcák, közterek férfiak által uralt, heteroszexuális terekként funkcionálnak, illetve termelődnek újjá.

\section{Vakmeró nók köztérhasználata}

A félelemföldrajzi vizsgálatok érdekes válfaját képviseli a vakmerő nők köztérhasználatának kutatása. Az ilyen vizsgálatok a félelmek helyett olyan helyzetekre koncentrálnak, amelyekben a nők cselekedetei (például a támadások elhárítása) azt bizonyítják, hogy magabiztos térhasználóként tekinthetünk rájuk. 
Koskela (1997) úgy látja, hasznos a nők közterekhez kapcsolódó félelmei mellett a bátorságra is koncentrálni a félelemföldrajzi kutatásokban. Azon a véleményen van, hogy a köztereket vakmerően használó nők bizonyítják, hogy a nők a köztereknek nemcsak passzív megtapasztalói, ezáltal maszkulin jellegének erősítői, hanem aktívan részt vesznek a közterek termelésében. Az efféle viselkedésformáknak azért van jelentősége, mert rámutatnak arra, hogy a nőkre nem kell született áldozatként tekinteni, illetve arra, hogy a közterek maszkulin karaktere igenis megkérdőjelezhető. Koskela (1997) azt gondolja, hogy

a társadalmi nemi viszonyok mentén eltérően eloszló társadalmi hatalom megértéséhez nem elegendo” szimplán egy nő és egy lehetséges támadó közötti kapcsolatot, sem pedig a köztereken közlekedő nók és férfiak közötti kapcsolatot vizsgálat alá venni. Nem „az egyének szintjén értelmezett” hatalom az, ami ebben az esetben érdekes, hanem a hatalom Foucault-féle $(1975,1980)$ felfogása, amely szerint a hatalom viszonylagos. A hatalom nem kebelez be minket, hanem a társadalmi élet minden kis szegmensében szétoszlik. Továbbá, a társadalmi hatalom nem feltétlenül negatív/elnyomó, nem érthetjük meg csupán az „elnyomott nök” és ", hatalommal rendelkezó férfiak" kategóriáin keresztül; a társadalmi hatalom az ellenállás lehetöségét is magában rejti (Koskela 1997, 312.).

Annak következtében, hogy a vakmerő nők tudatosan megkérdőjelezik a tér természetesnek gondolt maszkulinitását, annak a hatalmi berendezkedésnek egy lehetséges kritikáját is adják, amely leképeződéseként a közterek felfoghatók a Butlerre alapozó tértermelési elmélet szerint.

\section{Összegzés}

E tanulmány olyan feminista földrajzi elméletekről kívánt metszetet adni, amelyek a társadalmi tértermelésnek a társadalmi nem és szexualitás, illetve a büncselekményektől való félelem kontextusában történő kutatásához nyújtanak alapot. Célja annak bemutatása volt, hogy milyen hozadéka lehet egy ilyen jellegü vizsgálatnak, illetve mit tudhatunk meg a tér és társadalom (térhasználók) viszonyáról az ilyen jellegủ kutatások segítségével.

Összegzésként elmondható, hogy a társadalmi nemi viszonyok által erőteljesen áthatott büncselekményektől való félelemnek kettős térbeli következménye van. A fizikai tér és a térhasználók tekintetében a mobilitás csökkenésével jár, az egyes emberek (elsősorban a nők) kisebb magabiztossággal, stratégiák alkalmazásával használják a teret, a közterek kirekesztő terekké válnak, tehát demokratikus voltuk sérül. A társadalmi tér termelését illetően pedig az állapítható meg, hogy a büncselekményektől való félelem által kiváltott gyakorlati cselekvések és ismétlések fenntartják és erősítik a közterek maszkulin (és ezzel összefüggésben heteroszexuális) természetét. Fontos látni, hogy a tér anyagi és társadalmi dimenziói összefonódnak, és a fizikai tér esetén tapasztalható (mér- 
hető) kirekesztést a társadalmi tér termelését átható folyamatok irányítják. Tehát azért fontos vizsgálni a félelemmel összefüggő társadalmi tértermelés folyamatát, mert így feltárhatók és kritika alá vehetők azok a társadalmi jelenségek és erőviszonyok, amelyek áthatják.

Azonban fontos megjegyezni, hogy a tanulmányban sorra vett írások és koncepciók főleg angol-amerikai tapasztalatokra épülnek, márpedig a köztérhasználatban, társadalmi konstrukcióban lényeges kulturális eltérések lehetnek egyes országok között. Ezért zárásképpen megemlítek néhány, a köztérkutatáshoz kapcsolódó magyar cikket. Ennek célja az, hogy a tanulmányban felvázolt elméleti kerethez szolgáltasson kapcsolódási pontokat.

Gyáni hangsúlyozza, hogy a modern nagyváros kutatásában fontos szerep jut a „köz” és „magán” ellentétpárnak, hiszen ez a társadalmi tér strukturálásában fontos szerepet játszik. Amikor a nagyváros nyilvánosságszférájának funkcionális egyszerűsödéséről ír, rámutat, hogy e folyamat gyakorlati életre ható következményeként az „utcai és egyéb köztér nem tolerálja többé a magánéleti megnyilvánulásokat, vagy legalábbis csökken minden magánéletinek minősülő életfunkció ottani megjelenésének az esélye" (Gyáni 1990, 2.). Vajon vannak-e különbségek e téren egyes társadalmi csoportok között? Mely csoportok magánéleti megnyilvánulásai szorulnak inkább háttérbe, és miért? A jelen tanulmányban felvázolt elméleti keret segíthet a kérdések megválaszolásában.

A kirekesztő köztér fogalmának a magyar kutatásokban való megjelenésére példa lehet Misetics és Udvarhelyi (2010) hajléktalanokról szóló írása, amelyben a szerzők felsorolják a magyarországi hajléktalanok közterekről való kirekesztésének különböző megnyilvánulási formáit. Hangsúlyozzák a hajléktalanokat dehumanizáló diskurzus jelentőségét a probléma fenntartásában. Ahogy a „félős nő mítosza" (Day 2001) hozzájárul a nők közterekről való kirekesztéséhez, ugyanúgy járul hozzá a dehumanizáló diskurzus a hajléktalanok társadalomból és közterekről történő kirekesztéséhez.

Nagy (2009) pedig szegedi hajléktalanokról (és köztérhasználatukról) szóló írásában rámutatott arra, hogy a hajléktalanok világát a férfiak uralják. A területek (közterek) elosztását a férfiak végzik, szintén ők azok, akik meghatározzák a hierarchiát. Vajon mi az oka a hajléktalan nők dupla kitaszítottságának? A jelenség továbbgondolásához segítséget nyújthat a társadalmi tér termelését a társadalmi nem és szexualitás kontextusában tárgyaló feminista földrajzi megközelítés.

A jelen tanulmányban felvázolt kutatási téma szélesebb körü magyar kontextusba helyezésére egy következő írásban kerülhet sor. Az a véleményem, hogy a félelemföldrajzi vizsgálatoknak - és a feminista földrajznak általában Magyarországon is van/lenne létjogosultsága, hiszen e kutatások lehetővé teszik, hogy a földrajzi vizsgálatok központi kategóriáit, a teret és a térhasználókat eddig még elhanyagolt változók (társadalmi nem, szexualitás) mentén kezdjük el értelmezni. A vizsgálatok további hozadéka lehet a társadalmi egyenlőtlenségek okainak feltárása. A fent említett néhány példából látható, hogy e tanulmány egyes kulcsfogalmai (köz- és magántér, kirekesztő köztér) magyarországi kuta- 
tásokban is megjelennek. A kapcsolódó kérdések megválaszolásához azonban már az itt vázolt téma kutatása, a bemutatott elméleti megközelítések alkalmazása vihet közelebb.

\section{Jegyzetek}

1 Többszörös értelmezés is lehetséges, az értelmezések nem zárják ki egymást.

2 A „forgatókönyv” magyar viszonyokra való alkalmazhatóságát bizonyítja Timár (2004) magyar politikusnőkre irányuló kutatása. Ha ezen keresztül vizsgálat alá vesszük a politikát mint diszkurzív teret és a fizetett munka terét, akkor az állapítható meg, hogy a magán- és nyilvános szférák működését szabályozó „ideologikus forgatókönyv” aktívan befolyásolja a magyar nők politikai szerepvállalását, tehát alkalmazható a magyar társadalmi nemi viszonyok elemzésére. A kutatásban közölt interjúrészletek alapján látszik, hogy egyes politikusnőknek komoly lelkiismeret-furdalást okoz, hogy nem tudnak megfelelni a család intézménye körül keringetett ideológiai elvárásoknak. Az interjúalanyok arról is beszámolnak, hogy női mivoltuk kétségkívül szerepet játszik abban, hogy férfi kollégáik nem veszik őket komolyan politikusként. Ebben az esetben az látható, hogy a nőknek a magyar politikai életben való alulreprezentáltságához, előrejutásuk nehézségeihez az a társadalmi gyakorlat járul hozzá, amely a politikát maszkulin szféraként hozza létre, amelyben a nőt nem illetik meg ugyanolyan jogok, mint a férfit.

\section{Irodalom}

Brownlow, A. (2005): A Geography of Men's Fear. Geoforum, 36., 581-592.

Butler, J. (2006): Problémás nem. Feminizmus és az identitás felforgatása. Balassi Kiadó, Budapest

Connell, R. W. (1995): Masculinities. Polity Press, Cambridge

Day, K. (2001): Constructing Masculinity and Women's Fear in Public Space in Irvine, California. Gender, Place and Culture: A Journal of Feminist Geography, 2., 109-127.

Duncan, N. (1996): Renegotiating Gender and Sexuality in Public and Private Spaces. In: Duncan, N. (ed.): BodySpace. Destabilizing Geographies of Gender and Sexuality. Routledge, London \& New York, 127-144.

Gregory, D. (2000): Production of Space. In: Johnston, R. J., Gregory, D., Pratt, G., Watts, M. (ed.): The Dictionary of Human Geography. 2. kötet. Blackwell Publishing, Oxford, 644-647.

Gyáni G. (1990): A városi mikroterek társadalomtörténete. Tér és Társadalom, 1., 1-13.

Jagose, A. (2003): Bevezetés a Queer-elméletbe. Új Mandátum Könyvkiadó, Budapest

Koskela, H. (1997): Bold Walk and Breakings. Women's Spatial Confidence versus Fear of Violence. Gender, Place and Culture: A Journal of Feminist Geography, 3., 301-321.

Koskela, H. (2000): Gendered Exclusions. Women's Fear of Violence and Changing Relations to Space. Geografiska Annaler B, 2., 111-124.

Koskela, H. (2009): Fear of Crime. In: Kitchin R., Thrift N. (eds.): International Encyclopaedia of Human Geography. 2. kötet. Elsevier, Amsterdam \& Oxford, 334-339.

Koskela, H., Rachel, P. (2000): Revisiting Fear and Place. Women's Fear of Attack and the Built Environment. Geoforum, 31., 269-280.

Mahtani, M. (2004): Judith Butler. In: Hubbard, P., Kitchin, R., Valentine, G. (eds.): Key Thinkers on Space and Place. Sage Publications, London \& Thousand Oaks \& New Delhi, 65-71.

Misetics, B., Udvarhelyi, É. T. (2010): Otthontalan, csupa-csősz világ. Replika, 2., 43-57. 
Nagy, T. (2009): Átmenet a szocializmus rejtett hajléktalan világából a kvázi jóléti szociális védőhálóba. Tér és Társadalom, 3., 79-96.

Nameste, K. (1996): Genderbashing. Sexuality, Gender, and the Regulation of Public Space. Environment and Planning D: Society and Space, 2., 221-240.

Paddison, R., Sharp, J. (2007): Questioning the End of Public Space. Reclaiming Control of Local Banal Spaces. Scottish Geographical Journal, 2., 87-106.

Pain, R. (2000): Place, Social Relations and the Fear of Crime. A Review. Progress in Human Geography, 3., 365-387.

Pain, R. (2001): Gender, Race, Age and Fear in the City. Urban Studies, 5-6., 899-913.

Pratt, G. (2000): Private and Public Spheres. In: Johnston, R. J., Gregory, D., Pratt, G., Watts, M. (eds.): The Dictionary of Human Geography. Blackwell Publishing, Oxford, 636-637.

Rosewarne, L. (2007): Pin-ups in Public Space. Sexist Outdoor Advertising as Sexual Harassment. Women's Studies International Forum, 30., 313-325.

Staeheli, L. A., Mitchell, D. (2007): Locating the Public in Research and Practice. Progress in Human Geography, 6., 792-811.

Staeheli, L. A., Mitchell, D. (2009): Public Space. In: Kitchin, R., Thrift, N. (eds.): International Encyclopaedia of Human Geography. 8. kötet. Elsevier, Amsterdam \& Oxford, 511-516.

Starkweather, S. (2007): Gender, Perceptions of Safety and Strategic Responses Among Ohio University Students. Gender, Place and Culture: A Journal of Feminist Geography, 3., 355-370.

Timár, J. (1993): A nők tanulmányozása a földrajzban. Tér és Társadalom, 1-2., 1-18.

Timár, J. (2002): Feminista földrajz. In: Tóth J. (szerk.): Általános társadalomföldrajz I. Dialóg Campus Kiadó, Budapest-Pécs, 295-312.

Timár, J. (2004): Eltérő települési adottságok, közös női sorsok. In: Sáfrány R. (szerk.): Életpályák és mozgásterek. Nók a helyi közéletben. Magyarországi Női Alapítvány, Budapest, 29-47.

Valentine, G. (1989): The Geography of Women's Fear. Area, 4., 385-390.

Valentine, G. (1992): Images of Danger. Women's Sources of Information about the Spatial Distribution of Male Violence. Area, 1., 22-29.

Valentine, G. (1996): (Re)negotiating the "Heterosexual Street". Lesbian Productions of Space. In: Duncan, N. (ed.): BodySpace: Destabilizing Geographies of Gender and Sexuality. Routledge, London \& New York, 146-155.

Yeoh, B., Yeow, P. L. (1997): Where Women Fear to Tread. Images of Danger and the Effects of Fear of Crime in Singapore. GeoJournal, 3., 273-286. 